\title{
Impacts of dietary inclusion of dried brewers' grains on growth, carcass traits, meat quality, nutrient digestibility and blood biochemical indices of broilers
}

\author{
E.A. Ashour ${ }^{1}$, M.E. Abd El-Hack ${ }^{1 \#}$ M.M. El-Hindawy ${ }^{1}$, A.I. Attia ${ }^{1}$, A.O. Osman ${ }^{2}$, \\ A.A. Swelum ${ }^{3,4 \#}$, A.N. Alowaimer ${ }^{3}$, I.M. Saadeldin ${ }^{3,5}$ \& V. Laudadio ${ }^{6}$ \\ ${ }^{1}$ Poultry Department, Faculty of Agriculture, Zagazig University, Zagazig 44511, Egypt \\ ${ }^{2}$ Biochemistry Department, Faculty of Agriculture, Zagazig University, Zagazig 44511, Egypt \\ ${ }^{3}$ Department of Animal Production, College of Food and Agriculture Sciences, King Saud University, P.O. Box 2460, \\ Riyadh 11451, Saudi Arabia \\ ${ }^{4}$ Department of Theriogenology, Faculty of Veterinary Medicine, Zagazig University, Zagazig 44511, Egypt \\ ${ }^{5}$ Department of Physiology, Faculty of Veterinary Medicine, Zagazig University, Zagazig 44511, Egypt \\ ${ }^{6}$ Department of DETO, Section of Veterinary Science and Animal Production, University of Study of Bari 'Aldo Moro', \\ Valenzano, Bari, Italy
}

(Received 16 March 2019; Accepted 8 April 2019; First published online 22 June 2019)

\author{
Copyright resides with the authors in terms of the Creative Commons Attribution 4.0 South African License. \\ See: http://creativecommons.org/licenses/by/4.0/za \\ Condition of use: The user may copy, distribute, transmit and adapt the work, but must recognize the authors and \\ the South African Journal of Animal Science.
}

\begin{abstract}
The current investigation aimed to evaluate the effect of dietary inclusion of dried brewers' grains (DBG) on growth performance, carcass traits, meat quality, nutrient digestibility, blood biochemical constituents and antioxidant indices of broiler chickens. A total of 300 unsexed one-week-old Hubbard chicks were randomly allotted to five treatment groups. The dietary treatments consisted of a basal diet as the control and DBG groups (3\%,6\%, $9 \%$ and $12 \%$, respectively). The best feed conversion ratio (FCR) was found in the group of birds fed a diet containing 9\% DBG, compared the other groups. Dressing and abdominal fat percentages decreased significantly but gradually with the elevated DBG level in the diets from $6 \%$ to $12 \%$. The inclusion of DBG in broiler diets resulted in significant positive effects on all of the sensory evaluation indicators except appearance and tenderness. Broilers fed a diet containing 3\% DBG had significant higher of digestion coefficients for crude protein than those fed on the other experimental diets. Based on growth performance and health status, 3\% or 9\% DBG may be the optimum percentages for inclusion in the diets of poultry until six weeks old. In addition, DBG exerted several health benefits in meat, which would be reflected positively on human health.
\end{abstract}

Keywords: unconventional feedstuff, inclusion, performance, chicken, meat quality

\#Corresponding authors: dr.mohamed.e.abdalhaq@gmail.com, m.ezzat@zu.edu.eg; aswelum@ksu.edu.sa

\section{Introduction}

Among the challenges to the poultry industry in developing countries are the high prices of soybean meal and yellow corn, which are used mainly for the formulation of poultry diets. The cost of feed is between 65\% and 70\% (Al-Sagheer et al., 2019) and 70\% and 75\% (Abd El-Hack et al., 2015) of the total cost of production, as opposed to about $50 \%$ to $60 \%$ in developed countries (Saeed et al., 2017). The best strategy to reduce the cost of poultry feeds is to use alternative cheaper local ingredients (Abd El-Hack et al., 2015; Ashour et al., 2016). Reducing the cost of feed is therefore an important target in the poultry industry. Increased feed costs and limited amounts of animal protein sources in poultry feed have led to the use of alternative plant proteins that make up some or all animal protein in feed (El Boushy et al., 2000; Vasso \& Russ, 2007). Therefore, considerable attention has been given to the use of unconventional feedstuffs, such as agro-industrial by-products, in the formulation of poultry diets, with the intention of achieving suitable utilization and economic efficiency of poultry production (Alagawany et al., 2015; Abd El-Hack et al., 2017a; 2017b).

Dried brewers' grain (DBG) is a brewery by-product. The residue is obtained from barley, wheat, maize, rice and oats. DBG consists of the insoluble materials that remain after the process of soaking, 
mashing and boiling in water, and contains crude fibre (CF) fractions, ether extract (EE), crude protein (CP) and starch (Amire, 2001; Areghore \& Abdulrazak, 2005). DBG or spent grains can be fed to livestock in wet form or after drying. Because wet grains deteriorate easily, the product is usually dried to the DBG. Spent grain or DBG contains $93 \%$ dry matter (DM), 48.6\% nitrogen free extract (NFE), $22.4 \%$ CP, $19.1 \%$ CF, $6.2 \%$ $\mathrm{EE}, 4 \%$ ash and $2360 \mathrm{kcal} / \mathrm{kg}$ of metabolizable energy (ME) (Longe et al., 1983). DBG material is available in large quantities in Egypt. The Egyptian vision for 2030 is to decrease the importation of feedstuffs and make the best use of local materials. So, it is the responsibility of nutritionists to re-examine local feedstuffs (such as DBG) and try to use them as a replacement for maize and soybean meal.

Dried brewers' grain is high in $\mathrm{CP}$ and ME, and could be used to reduce the quantity of maize grain and soybean meal in broiler chicken diets. However, the use of DBG is limited in poultry diets because of its high fibre content. Therefore, the current trial was performed to evaluate on broilers the effect of various dietary inclusion levels of DBG on growth performance, carcass traits, serum metabolites, nutrient digestibility and quality of broiler meat.

\section{Materials and Methods}

The present investigation was carried out at Poultry Research Farm, Department of Poultry, Faculty of Agriculture, Zagazig University, Zagazig, Egypt. All authors gave their informed consent for inclusion before they participated in the study. The study was conducted in accordance with the guidelines of the Local Experimental Animal Care Committee, and the protocol was approved by the Ethics Committee of the Department.

A total of 300 one-week old unsexed Hubbard chicks, with an initial weight of $114.5 \pm 1.35 \mathrm{~g}$, were allotted to a complete randomized experimental design with five treatments and 60 chicks in six replicates $(5 \times 6 \times 10)$. Galvanized wire cages $(40 \mathrm{~cm}$ height $\times 50 \mathrm{~cm}$ width $\times 100 \mathrm{~cm}$ length) were used for housing (10 chicks per cage). Fresh water was available automatically and continuously. Feed treatments consisted of a basal diet (control) and DBG supplemented groups (3\%,6\%, 9\% and 12\% DBG). The choice of levels was based on a review of previous reports on the usage of DBG in poultry feed. Each group of broiler chicks was fed the experimental diet (in mash form) from one to six weeks old. The experimental diets were fed in two phases: starter (1 - 3 weeks) and finisher (3-6 weeks). Throughout the experiment, feed and water were available ad libitum. All chicks were kept under similar hygienic management (such as vaccinations) and environmental conditions. The chicks were fed according to their nutritional requirements (NRC, 1994). The formulation and composition of commercial broiler diets are provided in Tables 1 and 2. The chemical analysis of DBG used in the experiment was $20.9 \%$ CP, $15.3 \%$ crude fibre (CF), $6.2 \%$ crude fat and 2840 $\mathrm{kcal} / \mathrm{kg} \mathrm{ME}$, according to AOAC (2003).

The weight of each bird was recorded weekly. Average daily feed intake (FI), bodyweight gain (BWG) and feed conversion ratio (FCR) were calculated. Feed wastage was recorded daily to calculate FI. Ten birds per treatment were randomly selected for carcass evaluation. The weights of the carcasses were recorded in $\mathrm{kg}$, while the weights of the liver, gizzard, heart, thigh, breast and abdominal fat were recorded as $\mathrm{g} / \mathrm{kg}$ of slaughter weight. Dressed weights were calculated with this formula: ddressed weight $=$ (carcass weight + giblets weight) / live body weight\}. At the end of the experiment, blood samples were collected in sterilized tubes from 10 broiler chicks in each group. Samples were centrifuged at 2328.24 ( $g$ force) for 15 min to obtain serums, which were stored in Eppendorf tubes at $-20{ }^{\circ} \mathrm{C}$ until analysis. The serum biochemical constituents including total protein (TP), albumin (ALB), aspartate aminotransferase (AST, EC 2.6.1.1), alanine aminotransferase (ALT, EC 2.6.1.2), creatinine, urea, total cholesterol (TC), high density lipoprotein $(\mathrm{HDL})$, triglyceride (TG), malondialdehyde (MDA), glutathione peroxidase (GPx, EC 1.11.19) and glutathioneS-transferase (GSTs, EC 2.5.1.18) were evaluated spectrophotometrically using commercial diagnostic kits (Biodiagnostic Co., Giza, Egypt).

To calculate the economic efficiency of meat production, the amount of feed consumed during the entire experimental period and the final live bodyweight were considered. An economic evaluation of experimental diets was performed as the feed cost needed to obtain one kilogram of live bodyweight. The dominant market prices of various elements in the study were considered. The economic efficiency of the product (growth rate) was calculated from an input and output analysis based on the differences in growth rate and feeding costs (Sarbaz et al., 2018).

Digestion trials were conducted at the end of the experimental period (42 days old) to estimate the digestion coefficients of the diets. Five birds per treatment group were housed individually in metabolism cages. To ensure that all birds maintained their weight, they were weighed before and after the collection period. The metabolism cages were made of metallic wire with wooden frames and a drawer for excreta collection, with the dimensions of $50 \times 50 \times 50 \mathrm{~cm}$. A sheet of aluminium foil that covered the drawer facilitated excreta collection. Experimental diets and water were available ad libitum through fixed containers. A small drawer covered with a plastic sheet placed under the food trough was used to facilitate the collection 
of feed remnants. The objective of the preliminary period (three days) was to adjust feed intake and minimize residual feed during the collection period (four days), to obtain material that was suitable for chemical analysis.

Table 1 Formulation and chemical analysis of the starter diets through 1 - 3 weeks of age for broiler chicken

\begin{tabular}{|c|c|c|c|c|c|}
\hline \multirow{2}{*}{ Ingredients (\%) } & \multicolumn{5}{|c|}{ Inclusion levels of brewers' dried grains (\%) } \\
\hline & 0 & 3 & 6 & 9 & 12 \\
\hline Maize & 57.1 & 55.2 & 53.6 & 51.3 & 49.0 \\
\hline Soybean meal & 31.7 & 30.6 & 28.8 & 28.2 & 27.7 \\
\hline Gluten meal & 6.50 & 6.50 & 7.00 & 6.70 & 6.40 \\
\hline Brewers' dried grains & 0.00 & 3.00 & 6.00 & 9.00 & 12.00 \\
\hline Di Calcium & 1.70 & 1.70 & 1.70 & 1.70 & 1.70 \\
\hline Limestone & 1.24 & 1.22 & 1.22 & 1.22 & 1.20 \\
\hline Vitamin-mineral premix* & 0.30 & 0.30 & 0.30 & 0.30 & 0.30 \\
\hline $\mathrm{NaCl}$ & 0.30 & 0.30 & 0.30 & 0.30 & 0.30 \\
\hline DL Methionine & 0.05 & 0.04 & 0.03 & 0.02 & 0.02 \\
\hline L-Lysine & 0.13 & 0.14 & 0.16 & 0.16 & 0.15 \\
\hline Soybean oil & 1.00 & 1.04 & 0.90 & 1.10 & 1.30 \\
\hline Total & 100 & 100 & 100 & 100 & 100 \\
\hline \multicolumn{6}{|l|}{ Calculated analysis ${ }^{* *}$} \\
\hline Crude protein $\%$ & 23.0 & 23.0 & 23.0 & 23.0 & 23.0 \\
\hline ME Kcal/kg diet & 2951 & 2950 & 2951 & 2951 & 2951 \\
\hline Calcium \% & 1.00 & 1.00 & 1.00 & 1.00 & 1.00 \\
\hline Phosphorus (available) \% & 0.45 & 0.45 & 0.45 & 0.45 & 0.45 \\
\hline Lysine \% & 1.20 & 1.20 & 1.20 & 1.20 & 1.20 \\
\hline$M+C \%$ & 0.83 & 0.83 & 0.83 & 0.83 & 0.83 \\
\hline Crude fibre $\%$ & 3.56 & 3.90 & 4.20 & 4.57 & 4.93 \\
\hline \multicolumn{6}{|l|}{ Determined analysis ${ }^{* * *}$} \\
\hline Crude protein \% & 22.8 & 23.1 & 23.1 & 22.9 & 23.2 \\
\hline Crude fibre \% & 3.78 & 3.98 & 4.72 & 4.79 & 5.00 \\
\hline Pricel ton $(\$)^{* * * *}$ & 344.38 & 336.71 & 327.43 & 320.88 & 314.86 \\
\hline
\end{tabular}

* Vitamin and mineral premix - $2.5 \mathrm{~kg}$ contained: vitamin A, $12000000 \mathrm{IU}$; vitamin $\mathrm{D}_{3}, 2000000 \mathrm{IU}$; vitamin $\mathrm{E}, 10 \mathrm{~g}$; vitamin $\mathrm{K}_{3}, 2 \mathrm{~g}$; vitamin $\mathrm{B}_{1}, 1000 \mathrm{mg}$; vitamin $\mathrm{B}_{2}, 49 \mathrm{~g}$; vitamin $\mathrm{B}_{6}, 105 \mathrm{~g}$; vitamin $\mathrm{B}_{12}$, $10 \mathrm{mg}$; pantothenic acid, $10 \mathrm{~g}$; niacin, 20 g; folic acid, 1000 mg; biotin, 50 g; choline chloride, 500 mg, Fe 30 g; Mn, 40 g; Cu, 3 g; Co, 200 mg;

Si, $100 \mathrm{mg} ; \mathrm{Zn}, 45 \mathrm{~g}$

**According to NRC (1994)

***According to AOAC (2003)

**** Prices were calculated according the market price in 2019

NaCL: sodium chloride; ME: metabolizable energy

The experimental diets were weighed on the first day of the collection period and given once daily. At the end of the experiment, feed residue was weighed and subtracted from the total feed provided. Excreta collection began 24 hours after the start of the collection period. Feathers and scattered feed were separated from the excreta. To prevent any loss in ammonia during drying, the excreta were sprayed with $2 \%$ boric acid solution. The excreta of each bird during the collection period was pooled and dried at $65{ }^{\circ} \mathrm{C}$ for 24 hours. The dried excreta from three successive days were equilibrated with the atmosphere for a few hours, then ground, mixed thoroughly, and stored in glass jars for chemical analysis. The proximate analysis of tested 
material, feeds and dried excreta was carried out according to the protocols of the Association of Official Analytical Chemists (AOAC, 2003) using triplicate samples for each nutrient.

Table 2 Formulation and chemical analysis of the finisher diets for broiler chickens through 3 - 6 weeks old

\begin{tabular}{|c|c|c|c|c|c|}
\hline \multirow{2}{*}{ Ingredients (\%) } & \multicolumn{5}{|c|}{ Inclusion levels of brewers' dried grains (\%) } \\
\hline & 0 & 3 & 6 & 9 & 12 \\
\hline Maize & 60.5 & 58.4 & 57.1 & 55.1 & 53.3 \\
\hline Soybean meal & 27.2 & 26.3 & 24.1 & 23.1 & 21.8 \\
\hline Gluten meal & 6.10 & 6.00 & 6.65 & 6.65 & 6.80 \\
\hline Brewers' dried grains & 0.0 & 3.0 & 6.0 & 9.0 & 12.0 \\
\hline Di Calcium & 1.50 & 1.50 & 1.50 & 1.50 & 1.50 \\
\hline Limestone & 1.15 & 1.12 & 1.12 & 1.12 & 1.11 \\
\hline Vitamin-mineral premix* & 0.30 & 0.30 & 0.30 & 0.30 & 0.30 \\
\hline $\mathrm{NaCl}$ & 0.30 & 0.30 & 0.30 & 0.30 & 0.30 \\
\hline DL Methionine & 0.02 & 0.01 & 0.00 & 0.00 & 0.00 \\
\hline L-Lysine & 0.10 & 0.10 & 0.13 & 0.14 & 0.15 \\
\hline Soybean oil & 2.85 & 3.00 & 2.75 & 2.80 & 2.81 \\
\hline Total & 100 & 100 & 100 & 100 & 100 \\
\hline \multicolumn{6}{|l|}{ Calculated analysis** } \\
\hline Crude protein \% & 21.0 & 21.0 & 21.0 & 21.0 & 21.0 \\
\hline $\mathrm{ME} \mathrm{Kcal/kg} \mathrm{diet}$ & 3099 & 3102 & 3101 & 3100 & 3101 \\
\hline Calcium \% & 0.90 & 0.90 & 0.90 & 0.90 & 0.90 \\
\hline Phosphorus (available) \% & 0.40 & 0.40 & 0.40 & 0.40 & 0.40 \\
\hline Lysine \% & 1.05 & 1.05 & 1.05 & 1.05 & 1.05 \\
\hline$M+C \%$ & 0.74 & 0.74 & 0.74 & 0.75 & 0.76 \\
\hline Crude fibre \% & 3.31 & 3.66 & 3.95 & 4.29 & 4.62 \\
\hline \multicolumn{6}{|l|}{ Determined analysis } \\
\hline Crude protein \% & 21.2 & 21.0 & 21.1 & 20.6 & 21.7 \\
\hline $\mathrm{ME} \mathrm{Kcal/kg} \mathrm{diet}$ & 3111 & 3098 & 3135 & 3095 & 3109 \\
\hline Crude fibre $\%$ & 3.45 & 3.86 & 4.10 & 4.35 & 4.98 \\
\hline Pricel ton $(\$)^{\star * * *}$ & 338.25 & 331.36 & 320.93 & 313.61 & 305.81 \\
\hline
\end{tabular}

*Vitamin and mineral premix - $2.5 \mathrm{~kg}$ contained: vitamin A, $12000000 \mathrm{IU}$; vitamin $\mathrm{D}_{3}, 2000000 \mathrm{IU}$; vitamin E, $10 \mathrm{~g}$; vitamin $K_{3}, 2$ g; vitamin $B_{1}, 1000 \mathrm{mg}$; vitamin $B_{2}, 49 \mathrm{~g}$; vitamin $B_{6}, 105 \mathrm{~g}$; vitamin $B_{12}, 10 \mathrm{mg}$; pantothenic acid, $10 \mathrm{~g}$; niacin, $20 \mathrm{~g}$; folic acid, 1000 mg; biotin, 50 g; choline chloride, 500 mg; Fe, 30 g; Mn, 40 g; Cu, 3 g; Co, 200 mg;

Si, 100 mg; Zn, $45 \mathrm{~g}$

**According to NRC (1994)

***According to AOAC (2003)

**** Prices were calculated according the market price in 2019

NaCL: sodium chloride; ME: metabolizable energy

At the end of the experiment, chickens were slaughtered, plucked, dressed, washed in water, and cut into separate parts. Ten samples per treatment group were taken from the thigh (biceps femoris muscle) and breast (pectoralis major muscle). Three hundred grams from the thigh plus $300 \mathrm{~g}$ from the breast were cut into 3 - $4 \mathrm{~cm}$-thick steaks and minced in the laboratory using a Moulinex meat grinder $(1400 \mathrm{~W} / 600 \mathrm{~W}$ locked motor output, HV8, France). The basic formulation of chicken meat was (g/g) 952 meat, $2.5 \%$ spice mixture (50 g black pepper, $30 \mathrm{~g}$ cloves), $2 \%$ salt, with $3 \mathrm{~g}$ onion juice. Chicken patties $(50 \mathrm{~g})$ were grilled in an air oven, before being brushing with a small amount of corn oil and grilled under a moderate heat for 20 - 30 min at $190-200^{\circ} \mathrm{C}\left(375^{\circ} \mathrm{F}\right.$ (Nath et al., 1996) in an oven. 
Patty cooking yields (expressed as a percentage) were calculated as the ratio of the cooked weight to the raw weight of patties from each group. The cooking loss percentage was calculated as the difference in weight between individual raw and cooked patties. The moisture retention value was the amount of moisture retained in the cooked product per $100 \mathrm{~g}$ raw sample (Kumar \& Sharma, 2004).

Colour attributes of poultry meat $\left(L^{*}, a^{*}\right.$, and $\left.b^{*}\right)$ were evaluated using the Hunter Lab colour analyser (Colorflex EZ, USA), according to Rao et al. (2011). The $L^{*}$ value (lightness index scale) ranges from 0 (black) to 100 (white), $a^{*}$ value indicates the redness $(+a)$ or greenness $\left(-a^{*}\right)$, and the $b$ value refers to the yellowness $(+b)$ or blueness $\left(-b^{\star}\right)$. Samples (minced mix of thigh and breast muscles) filled petri dishes to the top, then the petri dish was placed directly on the colorimeter sensor.

$$
\Lambda E=[(l-l *) 2+(a-a *) 2+(b-b *) 2] 0.5
$$

where: $L^{*}, a^{*}$ and $b^{*}$ were the values of the reference sample, which refers to the control sample, and $(\wedge \mathrm{E})$ the total colour differences in comparison with an untreated control.

All samples at a temperature of $30-35^{\circ} \mathrm{C}$ were assessed for their appearance and colour, flavour and juiciness, by a panel of eight experienced judges using an 8-point descriptive scale, in which 8 denoted extremely desirable and 1 denoted extremely poor. Tap water was provided between samples to cleanse the palate. The results were expressed as the mean \pm standard error of mean (SEM) for eight patties/treatment.

The data (cage means) were assessed with a one-way ANOVA using the GLM procedures of SPSS (2008). The applied model was as follows:

$$
Y_{i j k}=\mu+T_{i}+e_{i j}
$$

where: $Y_{i j k}=$ an observation,

$\mu=$ the overall mean,

$\mathrm{T}_{\mathrm{i}}=$ effect of DBG inclusion levels $(0,3,6,9,12)$, and

$\mathrm{e}_{\mathrm{ij}}=$ random error.

The significant differences were assessed using Duncan's multiple range test. The results were expressed as mean values and standard error means (SEM). Statistical significance statements were based on $P<0.05$.

\section{Results and Discussion}

The results indicated that live body weight (LBW) at 6 weeks old and 8 through $3-6$ and 1 - 6 weeks old decreased $(P<0.05)$ in chicks fed diets containing DBG. The reduction in LBW and BWG increased with DBG levels from $3 \%$ to $12 \%$ (Table 3). Studies have shown that as the inclusion of DBG increases, birds do not compensate for the reduced dietary metabolizable energy levels and do not increase their feed intake (Denstadli et al., 2010). The present results agree with those obtained by Wondifraw \& Tamir (2014), who showed that growth rate generally decreased progressively with increasing levels of DBG in White Leghorn chicks, and concluded that DBG could be incorporated in chick rations up to $18 \%$ without an adverse effect on growth performance to increase economic efficiency. Adama et al. (2007) incorporated four levels of sorghum DBG up to $40 \%$ to replace maize and groundnut cake in broiler chicken diets, and reported that the growth rate remained similar up to $20 \%$, and then decreased. A study by Esonu et al. (1999) suggested that diets with $30 \%$ maize-sorghum-based DBG to replace maize showed similar performance to the control group with only maize, thus reducing the total cost of broiler production. Feeding DBG at the level of $20 \%$ (replacing maize and soybean meal) did not affect the BWG of Vanaraja chicks at 9 weeks old (Swain et al., 2012). Aghabeigi et al. (2013) concluded that the addition of DBG up 20\%, in broiler chick diets through 11 to 42 days and 5\% DBG through 25 to 42 days approached the growth of the control birds. Alabi et al. (2014) found that increasing the level of DBG up to $25 \%$ without commercial enzyme supplementation resulted in a decrease in weight gain. It could be concluded that merging DBG with the broiler diet did not have positive effects on growth performance traits. These conflicting results may be because of varying sources of DBG and experiment conditions.

Average FI values decreased with increasing dietary DBG throughout the experimental period (1 - 6 weeks old) (Table 3). The present results agree those of Wondifraw \& Tamir (2014), who reported a small difference in the mean dry matter intake between starter chicks that were fed with 25\% DBG and their counterparts that were fed the control diet. This represents an advantage for breeders, as DBG is regarded as a waste material that can be purchased cheaply, and can thus reduce the production cost without 
Table 3 Growth performance of broiler chickens from 1 to 6 weeks old as affected by various levels of dried brewers' grains

\begin{tabular}{|c|c|c|c|c|c|c|c|c|c|c|c|c|c|c|}
\hline \multirow{2}{*}{$\begin{array}{l}\text { Dried brewers' } \\
\text { grains (\%) }\end{array}$} & \multirow{2}{*}{$\begin{array}{l}\text { Number } \\
\text { of pens }\end{array}$} & \multicolumn{3}{|c|}{ Live bodyweight (g) } & \multicolumn{3}{|c|}{ Bodyweight gain (g) } & \multicolumn{3}{|c|}{ Feed intake (g DM/day) } & \multicolumn{3}{|c|}{$\begin{array}{l}\text { Feed conversion } \\
\text { (g feed/g gain) }\end{array}$} & \multirow{2}{*}{$\begin{array}{l}\text { Economic } \\
\text { efficiency }\end{array}$} \\
\hline & & $1 \mathrm{wk}$ & 3 wk & $6 \mathrm{wk}$ & $\begin{array}{l}1 \text { - } 3 \\
\text { wk }\end{array}$ & $\begin{array}{l}3-6 \\
\text { wk }\end{array}$ & $\begin{array}{l}1-6 \\
\text { wk }\end{array}$ & $\begin{array}{l}1-3 \\
\text { wk }\end{array}$ & $\begin{array}{l}3-6 \\
\text { wk }\end{array}$ & $\begin{array}{l}1-6 \\
\text { wk }\end{array}$ & $\begin{array}{l}1-3 \\
\text { wk }\end{array}$ & $\begin{array}{l}3-6 \\
\text { wk }\end{array}$ & $\begin{array}{c}1-6 \\
\text { wk }\end{array}$ & \\
\hline 0 & 6 & 112.7 & 581.0 & $1876^{a}$ & 33.5 & $61.7^{\mathrm{a}}$ & $50.4^{\mathrm{a}}$ & 65.0 & 156.5 & 111.0 & 2.00 & 2.53 & 2.20 & $0.88^{\mathrm{ab}}$ \\
\hline 3 & 6 & 114.2 & 525.7 & $1749^{\mathrm{ab}}$ & 29.4 & $58.3^{\mathrm{ab}}$ & $46.7^{\mathrm{ab}}$ & 59.7 & 147.8 & 103.7 & 2.00 & 2.53 & 2.21 & $0.76^{\mathrm{bc}}$ \\
\hline 6 & 6 & 115.3 & 572.5 & $1651^{b}$ & 32.7 & $51.4^{b}$ & $43.9^{b}$ & 63.7 & 142.5 & 103.3 & 2.00 & 2.83 & 2.35 & $0.76^{\mathrm{bc}}$ \\
\hline 9 & 6 & 115.5 & 562.2 & $1747^{\mathrm{ab}}$ & 31.9 & $56.4^{\mathrm{ab}}$ & $46.6^{\mathrm{ab}}$ & 61.0 & 134.5 & 98.0 & 1.90 & 2.40 & 2.10 & $0.98^{a}$ \\
\hline 12 & 6 & 114.8 & 561.7 & $1409^{c}$ & 31.9 & $40.3^{c}$ & $37.0^{c}$ & 61.0 & 134.4 & 98.0 & 1.93 & 3.33 & 2.65 & $0.64^{c}$ \\
\hline SEM & & 0.38 & 11.83 & 46.11 & 0.84 & 2.19 & 1.13 & 0.97 & 3.97 & 2.27 & 0.05 & 0.12 & 0.06 & 0.02 \\
\hline$P$-value & & 0.085 & 0.700 & 0.001 & 0.691 & 0.001 & 0.002 & 0.443 & 0.371 & 0.383 & 0.962 & 0.068 & 0.093 & 0.001 \\
\hline
\end{tabular}

*Each pen involved 10 birds

Means in the same column with no superscript or a common superscript are not significantly different $(P<0.05)$ 
affecting $\mathrm{FI}$ (Wondifraw \& Tamir, 2014). With regard to FCR, it was not strongly affected by the addition of DBG to the diet of broiler chicks throughout the experiment (Table 3). This may be because of the reduction in BWG as a result of DBG inclusion. DBG contains a high concentration of non-starch polysaccharides and tannins, which have been shown to interfere with the efficiency of feed utilization in monogastric organisms, thus inhibiting the absorption of essential nutrients and digestive enzymes, and hence decreasing feed utilization (Lacassagne, 1998). Furthermore, Alabi et al. (2014) demonstrated that when the dietary level of BDG increased, FCR decreased. Data in Table 3 showed that broiler chicks exposed to 9\% BDG recorded the best $(P<0.01)$ economic efficiency value compared with the other treatments. This group showed the best feed conversion $(P>0.01)$ (Table 3$)$.

The various DBG levels did not have an effect on carcass and giblet percentages, apart from dressing percentage and abdominal fat relative weights $(P>0.05)$ (Table 4). Dressing and abdominal fat percentages decreased $(P<0.05)$ gradually with the increasing DBG level in the diets from $6 \%$ to $12 \%$ which may be because of lower bodyweight. Lopez \& Carmona (1981) evaluated DBG at levels of 0\%, 10\%, 20\%, 30\% and $40 \%$ in broiler chick diets, and reported minor differences in average dressing percentage up to the $20 \%$ inclusion level $(P>0.05)$. These authors observed that when a DBG inclusion level of $20 \%$ or more was used, there was a reduction in abdominal fat pads and meat tissue $(P<0.05)$, though no effect was observed in bone tissue. Additionally, Chumpawadee et al. (2008) reported that the inclusion of DBG in broiler diets did not induce an effect on carcass cuts $(P>0.05)$. Kokol et al. (2012) found that most carcass traits that were evaluated were not affected by DBG inclusion level $(P<0.05)$, apart from gizzard percentages, which varied among groups $(P<0.05)$.

Table 4 Carcass characteristics of broiler chickens from 1 to 6 weeks old as affected by various levels of dried brewers' grain

\begin{tabular}{|c|c|c|c|c|c|c|c|c|c|}
\hline \multirow{2}{*}{$\begin{array}{l}\text { Dried } \\
\text { brewers' } \\
\text { grains } \\
(\%) \\
\end{array}$} & \multirow{2}{*}{$\begin{array}{l}\text { Number } \\
\text { of birds }\end{array}$} & \multicolumn{7}{|c|}{ Weights relative to live weight (\%) } & \multirow{2}{*}{$\begin{array}{c}\text { Caecum } \\
\text { length } \\
\text { (cm) }\end{array}$} \\
\hline & & Dressing & Carcass & Giblets & Liver & Heart & Gizzard & $\begin{array}{c}\text { Abdominal } \\
\text { fat }\end{array}$ & \\
\hline 0 & 10 & $75.8^{\mathrm{a}}$ & 70.4 & 5.40 & 2.49 & 0.57 & 2.34 & $2.01^{a}$ & 19.6 \\
\hline 3 & 10 & $75.4^{\mathrm{a}}$ & 69.6 & 5.82 & 2.79 & 0.59 & 2.45 & $1.87^{\mathrm{b}}$ & 21.5 \\
\hline 6 & 10 & $74.6^{\mathrm{ab}}$ & 69.2 & 5.37 & 2.51 & 0.64 & 2.22 & $1.38^{\mathrm{c}}$ & 18.5 \\
\hline 9 & 10 & $73.5^{\mathrm{b}}$ & 67.9 & 5.52 & 2.60 & 0.61 & 2.31 & $1.04^{d}$ & 21.0 \\
\hline 12 & 10 & $73.2^{b}$ & 67.8 & 5.41 & 2.59 & 0.56 & 2.27 & $0.66^{\mathrm{e}}$ & 19.0 \\
\hline SEM & & 0.34 & 0.36 & 0.09 & 0.04 & 0.02 & 0.05 & 0.07 & 0.43 \\
\hline$P$-value & & 0.020 & 0.090 & 0.530 & 0.204 & 0.639 & 0.705 & 0.031 & 0.101 \\
\hline
\end{tabular}

Means in the same column with no superscript or with common superscripts are not significantly different $(P<0.05)$

The effects of DBG levels on colour values of broiler chicken meat, compared with the control, are presented in Tables 5 and 6 . Increased DBG levels was associated with elevated $L^{*}$ and $b^{*}$ values, and decreased $a^{*}$ values. The increase in protein concentration in meat is responsible for increasing lightness $\left(L^{*}\right)$ and decreasing redness $\left(a^{*}\right)$ values (Su et al., 2000; Rhee \& Ziprin, 2001). Munekata et al. (2015) suggested that variations in $L^{*}$ values may depend on phenolic concentrations. O'Keefe \& Wang (2006) reported a reduction in $L^{*}$ values with elevations in phenolic content, at concentrations in excess of 400 parts per million in ground cooked beef $(P<0.05)$. Sensory evaluations of broiler chicken meat, which involved tests of appearance, flavour, tenderness, texture, juiciness and cooking loss, were all affected by DBG inclusion $(P<0.05$ (Table 6). All meat samples from DBG groups showed lower appearance and tenderness values, compared with the control group $(P<0.05)$. All samples decreased in cooking loss percentage, compared with the control $(11.40 \% \pm 0.43)$. The opposite trend was observed in other sensory traits (flavour, texture and juiciness), which increased as a response to DBG inclusion $(P<0.001)$. Therefore, the inclusion of DBG in broiler diets exerts significant positive effects on the sensory properties of broiler chicken meat.

The results revealed that the digestibility coefficient values for DM and CF were not affected by DBG $(P>0.05)$ (Table 7). On the other hand, the digestibility coefficients of OM, CP, EE and NFE were affected $(P<0.01$ or $P<0.05)$ by feeding treatments. The results showed a decrease in digestion coefficients for the 
Table 5 Meat colour of samples as affected by various levels of dried brewers' grains from 1 to 6 weeks old

\begin{tabular}{|c|c|c|c|c|}
\hline \multirow{2}{*}{$\begin{array}{l}\text { Dried brewers' grains } \\
(\%)\end{array}$} & \multirow{2}{*}{ Number of birds } & \multicolumn{3}{|c|}{ Colour } \\
\hline & & $L^{*}$ & $a^{*}$ & $b^{\star}$ \\
\hline 0 & 10 & $46.7^{d}$ & $7.83^{\mathrm{a}}$ & $12.57^{d}$ \\
\hline 3 & 10 & $47.0^{d}$ & $6.73^{b}$ & $13.43^{c}$ \\
\hline 6 & 10 & $56.0^{c}$ & $5.90^{c}$ & $13.80^{\mathrm{C}}$ \\
\hline 9 & 10 & $66.3^{b}$ & $4.70^{\mathrm{d}}$ & $15.17^{b}$ \\
\hline 12 & 10 & $74.0^{\mathrm{a}}$ & $3.70^{\mathrm{e}}$ & $15.90^{\mathrm{a}}$ \\
\hline SEM & & 2.89 & 0.39 & 0.33 \\
\hline$P$-value & & 0.001 & $<0.00$ & $<0.00$ \\
\hline
\end{tabular}

$L^{*}$ : whiteness; $a^{*}$ : redness; $b^{*}$ : yellowness

Means in the same column with no superscript or with common superscripts are not significantly different $(P<0.05)$

Table 6 Sensory evaluation and cooking loss of broiler chicken meat using one to one mix of biceps femoris muscle of thigh and pectoralis major muscle of breast as affected by various levels of dried brewers' grains from 1 to 6 weeks old

\begin{tabular}{|c|c|c|c|c|c|c|c|}
\hline $\begin{array}{l}\text { Dried } \\
\text { brewers' } \\
\text { grains (\%) }\end{array}$ & $\begin{array}{l}\text { Number } \\
\text { of birds }\end{array}$ & Appearance & Flavour & Tenderness & Juiciness & Texture & $\begin{array}{c}\text { Cooking } \\
\text { loss }\end{array}$ \\
\hline 0 & 10 & $7.97^{\mathrm{a}}$ & $5.27^{c}$ & $7.70^{\mathrm{a}}$ & $6.53^{d}$ & $7.03^{b}$ & $11.40^{\mathrm{a}}$ \\
\hline 3 & 10 & $7.60^{b}$ & $5.97^{a}$ & $7.50^{\mathrm{ab}}$ & $7.63^{a}$ & $7.53^{a}$ & $7.20^{d}$ \\
\hline 6 & 10 & $7.47^{b}$ & $5.60^{b}$ & $7.03^{b}$ & $7.40^{\mathrm{bc}}$ & $7.57^{\mathrm{a}}$ & $9.00^{c}$ \\
\hline 9 & 10 & $7.10^{c}$ & $5.55^{b}$ & $6.83^{b}$ & $7.33^{c}$ & $7.43^{a}$ & $9.80^{b}$ \\
\hline 12 & 10 & $6.87^{c}$ & $5.80^{\mathrm{ab}}$ & $7.03^{b}$ & $7.60^{\mathrm{ab}}$ & $7.53^{a}$ & $7.27^{d}$ \\
\hline SEM & & 0.11 & 0.09 & 0.09 & 0.11 & 0.06 & 0.43 \\
\hline$P$-value & & $<0.000$ & 0.001 & $<0.000$ & $<0.000$ & $<0.000$ & $<0.000$ \\
\hline
\end{tabular}

Means in the same column with no superscript or with common superscripts are not significantly different $(P<0.05)$

9\% DBG level, compared with other groups and the control $(P<0.01$ or $P<0.05)$. However, the digestion coefficients of EE decreased for chicks fed 3\% DBG levels $(P<0.01)$. The highest CP digestion coefficient was obtained from groups with a diet that contained 3\% DBG $(P<0.01)$. Likewise, Aghabeigi et al. (2013) evaluated the impact of a gradual replacement of soybean meal with $0 \%, 5 \%, 10 \%, 15 \%, 20 \%$ and $25 \%$ DBG on protein digestibility in broiler chickens. The ileal protein digestibility was recorded from chicken samples slaughtered at 42 days old and was increased with the inclusion of $10 \%$ DBG in diets, compared with the $0 \%, 5 \%, 15 \%$, and 20\% DBG groups $(P<0.05)$. Conversely, Denstadli et al. $(2010)$ observed a reduction in protein digestibility as DBG replaced a wheat and soy-based control diet, probably because of the insoluble properties of the DBG protein. These authors added that apparent ash availability decreased gradually due to the inclusion of DBG in the diets, which was attributed to the complexation between fibrous structures of DBG and minerals. Adama et al. (2007) incorporated four levels of sorghum DBG, up to 40\%, in broiler chickens, which replaced maize and groundnut cake in the diet, and reported that the digestibility of all nutrients (CP, EE, NFE, and ash) decreased with increasing levels of DBG, but was not generally affected dramatically up to $20 \%$ levels of DBG.

No substantial impact of DBG inclusion was detected on any of the constituents, except from globulin, A/G ratio and HDL-cholesterol (Table 8$)$. The highest $(P=0.038)$ globulin concentration value was recorded for broiler chicks fed diets containing 3\% DBG $(3.67 \mathrm{~g} / \mathrm{dL})$. The broilers fed the diet supplemented with $9 \%$ DBG had the best albumin/globulin ratio (A/G) (0.48), compared with other levels. The HDL concentration differed statistically according to DBG levels. Serum HDL concentration recorded the highest value for chicks fed $12 \%$ DBG. These results may be because of the existence of bioactive components in DBG. Decreasing 
the concentration of serum LDL might be because of minimizing microbial intracellular pH (Abdo \& Zeinb, 2004). The inhibition of microbial enzymes forced the bacterial cell membrane to use energy to release acidic protons, which leads to a decline in intracellular pH (Aruna \& Srilatha, 2012).

Table 7 Digestibility coefficients of broiler chickens as affected by various levels of dried brewers' grains in the diet from 1 to 6 weeks old

\begin{tabular}{lccccccc}
\hline $\begin{array}{l}\text { Dried } \\
\text { brewers' } \\
\text { grains (\%) }\end{array}$ & $\begin{array}{c}\text { No. } \\
\text { of birds }\end{array}$ & DM & OM & CP & EE & NFE & CF \\
\hline $0 \%$ & 5 & 77.2 & $79.5^{\mathrm{a}}$ & $82.8^{\mathrm{c}}$ & $76.6^{\mathrm{ab}}$ & $82.1^{\mathrm{a}}$ & 23.4 \\
$3 \%$ & 5 & 78.5 & $80.5^{\mathrm{a}}$ & $88.1^{\mathrm{a}}$ & $69.0^{\mathrm{c}}$ & $82.2^{\mathrm{a}}$ & 24.1 \\
$6 \%$ & 5 & 78.0 & $78.9^{\mathrm{a}}$ & $86.7^{\mathrm{ab}}$ & $75.3^{\mathrm{b}}$ & $78.4^{\mathrm{b}}$ & 24.0 \\
$9 \%$ & 5 & 77.9 & $74.7^{\mathrm{b}}$ & $85.7^{\mathrm{b}}$ & $76.8^{\mathrm{ab}}$ & $73.9^{\mathrm{b}}$ & 23.8 \\
$12 \%$ & 5 & 78.4 & $81.7^{\mathrm{a}}$ & $85.8^{\mathrm{b}}$ & $79.2^{\mathrm{a}}$ & $83.5^{\mathrm{a}}$ & 23.4 \\
SEM & & 0.75 & 0.84 & 0.54 & 1.25 & 0.95 & 0.65 \\
$P$-value & & 0.546 & 0.002 & 0.003 & 0.002 & 0.001 & 0.632 \\
\hline
\end{tabular}

DM: dry matter; OM: organic matter; CP: crude protein; EE: ether extract; NFE: nitrogen free extract; CF: crude fibre Means in the same column with no superscript or with common superscripts are not significantly different $(P<0.05)$

Table 8 Serum protein and lipid profiles of broiler chickens as affected by various levels of dried brewers' grains in the diet from 1 to 6 weeks old

\begin{tabular}{|c|c|c|c|c|c|c|c|c|c|}
\hline $\begin{array}{l}\text { Dried } \\
\text { brewers' } \\
\text { grains } \\
(\%) \\
\end{array}$ & $\begin{array}{l}\text { No of } \\
\text { birds }\end{array}$ & $\begin{array}{c}\text { Tot } \\
\text { prot } \\
\text { (g/dL) }\end{array}$ & $\begin{array}{l}\text { Album } \\
\text { (g/dL) }\end{array}$ & $\begin{array}{l}\text { Glob } \\
\text { (g/dL) }\end{array}$ & $\begin{array}{l}A / G \\
\text { ratio }\end{array}$ & $\begin{array}{l}\text { Triglyc } \\
\text { (mg/dL) }\end{array}$ & $\begin{array}{l}\text { Total } \\
\text { chol } \\
\text { (mg/dL) }\end{array}$ & $\begin{array}{c}\text { LDL } \\
\text {-chol } \\
\text { (mg/dL) }\end{array}$ & $\begin{array}{c}\text { HDL } \\
\text { chol } \\
\text { (mg/dL) }\end{array}$ \\
\hline 0 & 10 & 3.80 & 1.16 & $2.64^{b}$ & $0.44^{\mathrm{a}}$ & 35.4 & 131.0 & 64.3 & $58.3^{\mathrm{b}}$ \\
\hline 3 & 10 & 4.67 & 1.00 & $3.67^{\mathrm{a}}$ & $0.27^{c}$ & 70.3 & 132.0 & 59.6 & $59.7^{b}$ \\
\hline 6 & 10 & 4.43 & 1.32 & $3.11^{\mathrm{ab}}$ & $0.43^{\mathrm{a}}$ & 42.3 & 146.6 & 66.5 & $71.7^{\mathrm{ab}}$ \\
\hline 9 & 10 & 3.79 & 1.23 & $2.56^{\mathrm{b}}$ & $0.48^{\mathrm{a}}$ & 25.1 & 137.7 & 73.0 & $59.7^{b}$ \\
\hline 12 & 10 & 4.00 & 1.08 & $2.93^{\mathrm{ab}}$ & $0.37^{\mathrm{b}}$ & 55.1 & 154.7 & 65.4 & $78.3^{\mathrm{a}}$ \\
\hline SEM & & 0.15 & 0.05 & 0.14 & 0.02 & 6.57 & 4.01 & 2.65 & 2.64 \\
\hline$P$-value & & 0.239 & 0.184 & 0.038 & $<0.000$ & 0.219 & 0.294 & 0.682 & 0.020 \\
\hline
\end{tabular}

Tot prot: total protein; Album: albumin; Glob: globulin; A/G: albumin/ globulin ratio; Triglyc: triglycerides; chol: cholesterol; LDL: Iow-density lipoprotein; HDL: high-density lipoprotein

Means in the same column with no superscript or with common superscripts are not significantly different $(P<0.05)$

The effects of dietary DBG on liver and kidney function and blood oxidative status were unique. Apart from serum ALT activity, all other constituents were affected statistically because of DBG inclusion levels (Table 9). Increasing the dietary DBG level was associated with a gradual elevation $(P=0.019)$ in the activity of glutathione peroxidase enzymes and a depression $(P<0.01)$ in the serum AST activity, and urea, creatinine and MDA levels. This result indicates an improvement in the kidney and liver function, along with oxidative status. Enhancement of immune functions in treatment groups may be because herbal supplements and plant-derived materials such as DBG have a rich content of flavonoids, which act as strong antioxidants (Acamovic \& Brooker, 2005). The main role of glutathione peroxidase enzymes is to prevent cells from oxidative damage. This process requires dietary resources of specific nutrients (Ashour et al., 2014). The present conclusions are in line with those of Lin et al. (2003), who found that the intake of plantderived components caused an increase in serum antioxidant enzyme activities and a reduction in MDA levels. Abd El-Hack (2015) and Alagawany et al. (2015) detected that dietary supplements of herbs into 
rabbit diets led to positive effects on antioxidant agents activities. From these findings, it can be inferred that DBG is a source of natural antioxidants and can be utilized in future to enhance the health status of broilers (Abd El-Hack et al., 2019).

Table 9 Liver and kidney functions and the antioxidative status of broilers as affected by various levels of dried brewers' grains in the diet from 1 to 6 weeks old

\begin{tabular}{|c|c|c|c|c|c|c|c|c|}
\hline $\begin{array}{l}\text { Dried } \\
\text { brewers' } \\
\text { grains (\%) }\end{array}$ & $\begin{array}{l}\text { Number } \\
\text { of birds }\end{array}$ & $\begin{array}{c}\text { AST } \\
\text { (IU/L) }\end{array}$ & $\begin{array}{c}\text { ALT } \\
\text { (IU/L) }\end{array}$ & $\begin{array}{c}\text { Urea } \\
\text { (mg/dL) }\end{array}$ & $\begin{array}{c}\text { Creatinine } \\
\text { (mg/dL) }\end{array}$ & $\begin{array}{c}\text { MDA } \\
(\mathrm{mol} / \mathrm{mg})\end{array}$ & $\begin{array}{l}\text { GPx } \\
\text { (IU/L) }\end{array}$ & $\begin{array}{l}\text { GSTs } \\
\text { (IUL) }\end{array}$ \\
\hline 0 & 10 & $18.33^{\mathrm{a}}$ & 269 & $46.0^{\mathrm{a}}$ & $0.85^{a}$ & $3.75^{a}$ & $2.71^{c}$ & 3.55 \\
\hline 3 & 10 & $11.67^{b}$ & 287 & $44.7^{\mathrm{ab}}$ & $0.82^{a b}$ & $3.66^{b}$ & $2.73^{b c}$ & 3.55 \\
\hline 6 & 10 & $15.80^{\mathrm{a}}$ & 279 & $44.3^{\mathrm{ab}}$ & $0.80^{\mathrm{ab}}$ & $3.61^{b}$ & $2.77^{\mathrm{ab}}$ & 3.56 \\
\hline 9 & 10 & $9.27^{b}$ & 283 & $43.0^{b}$ & $0.76^{b}$ & $3.52^{c}$ & $2.79^{\mathrm{a}}$ & 3.54 \\
\hline 12 & 10 & $6.50^{\mathrm{c}}$ & 248 & $41.0^{c}$ & $0.65^{c}$ & $3.38^{d}$ & $2.76^{\mathrm{ab}}$ & 2.39 \\
\hline SEM & & 1.19 & 10.9 & 0.51 & 0.02 & 0.03 & 0.01 & 0.24 \\
\hline$P$-value & & $<0.000$ & 0.847 & 0.002 & $<0.000$ & $<0.000$ & 0.019 & 0.479 \\
\hline
\end{tabular}

AST: aspartate aminotransferase; ALT: alanine aminotransferase; MDA: malondialdehyde; GPx: glutathione peroxidase; GSTs: glutathione-S-transferase

Means in the same column with no superscript or with common superscripts are not significantly different $(P<0.05)$

\section{Conclusions}

From the data, the conclusion could be drawn that including DBG in broiler diets did not have positive effects on growth performance traits. If blood biochemical constituents and nutrient digestibility are considered, $3 \%$ or $9 \%$ DBG may be the optimal percentage for inclusion in diets of poultry up to 6 weeks old.

\section{Acknowledgements}

This work was supported financially by the Deanship of Scientific Research at King Saud University through a research group project (\#RG-1438-018).

\section{Authors' Contributions}

EA, MEH and AA designed the study plan. MAEH collected literature and drafted the manuscript. AO helped in conducting research work. AS, ANA and IS provided technical help in the write-up of this manuscript. MAEH reviewed and performed the final check. All authors read and approved the final manuscript.

\section{Conflicts of Interest Declaration}

The authors declare there is no conflict of interest.

\section{References}

Abd El-Hack, M.E., 2015. Enzymes drying to be used in low-cost animal fodder production for existing biotechnology company. PhD thesis, Zagazig University, Zagazig, Egypt.

Abd El-Hack, M.E., Alagawany, M., Farag, M.R. \& Dhama, K., 2015. Use of maize distiller's dried grains with solubles (DDGS) in laying hen diets: Trends and advances. Asian J. Anim. Vet. Adv. 10, 690-707.

Abd El-Hack, M.E., Alagawany, M., El-Sayed, S.A.A. \& Fowler, J., 2017a. Influence of dietary inclusion of untreated or heat-treated Jatropha meal on productive and reproductive performances and biochemical blood parameters of laying Japanese quail. Poult. Sci. 96, 2761-2767.

Abd El-Hack, M.E., El-Hindawy, M.M., Attia, A.I. \& Mahrose, K.M., 2017b. Does the use of distiller's dried grains with solubles (DDGS) in layer diets affect the nutrients digestibility and manure pollution by nitrogen and phosphorous? Environ. Sci. Poll. Res. 24, 13335-13343.

Abd El-Hack, M.E., Alagawany, M., Patra, A., Abdel-Latef, M., Ashour, E.A., Arif, M., Farag, M.R. \& Dhama, K., 2019. Use of brewers dried grains as an unconventional feed ingredient in the diets of broiler chickens: A review. Adv. Anim. Vet. Sci. 7, 218-224.

Abdo M., Zeinb A., 2004. Efficacy of acetic acid in improving the utilization of low protein-low energy broiler diets. Egypt Poult. Sci. 24, 123-41.

Acamovic, T. \& Brooker, J.D., 2005. Biochemistry of plant secondary metabolites and their effects in animals. Proc. Nutr. Soc. $64,403-412$. 
Adama, T.Z., Ogunbajo, S.A. \& Mambo, M., 2007. Feed intake, growth performance and nutrient digestibility of broiler chicks fed diets containing varying levels of sorghum dried brewers' grains. Inter. J. Poult. Sci. 6, 592-598.

Aghabeigi R., Moghaddaszadeh-Ahrabi, S. \& Afrouziyeh, M., 2013. Effects of brewer's spent grain on performance and protein digestibility in broiler chickens. Euro. J. Exp. Bio. 3, 283-286.

Alabi, O.O., Atteh, J.O., Adejumo, I.O. \& Ogundele, O.O., 2014. Effects of dietary levels of brewers' dried grain supplemented with commercial enzymes on performance, nutrient retention and gastro-intestinal tract characteristics of Arbor Acres broilers. Int. J. Agri. Innov. Res. 2, 2319-1473.

Alagawany, M., Farag, M.R., Abd El-Hack, M.E. \& Dhama, K., 2015. The practical application of sunflower meal in poultry nutrition. Adv. Anim. Vet. Sci. 3, 634-648.

Al-Sagheer, A.A., Abd El-Hack, M.E., Alagawany, M., Naiel, M.A., Mahgoub, S.A., ..., Swelum, A.A., 2019. Paulownia leaves as a new feed resource: Chemical composition and effects on growth, carcasses, digestibility, blood biochemistry, and intestinal bacterial populations of growing rabbits. Animals 9,95

Amire, H.N., 2001. Nutrition affects immune responses in poultry. World Poult. J. 17, 42.

AOAC (Association of Official Analytical Chemists), 2003. Official methods of analysis. Volume 2. 16th edition. Washington DC.

Areghore, E.M. \& Abdulrazak, S.A., 2005. Estimation of organic matter digestibility and metabolizable energy content of agro- industrial waste using in vitro gas production. Nigerian J. Anim. Prod. 32, 10-89.

Aruna, M. \& Srilatha, N., 2012. Water clarification using Moringa oleifera Lam. seed as a natural coagulant. Current Biotica 5, 472-486.

Ashour, E.A., Alagawany, M., Reda, F.M. \& Abd El-Hack, M.E., 2014. Effect of supplementation of Yucca schidigera to growing rabbits diets on growth performance, carcass characteristics, serum biochemistry and liver oxidative status. Asian J. Anim. Vet. Adv. 9, 732-742.

Ashour, E.A., Reda, F.M. \& Abd El-Hack, M.E., 2016. The influences of partially replacement of maize corn by broken rice and sugar beet pulp on growth performance, carcass traits and economics of meat type quails. Iran. J. Appl. Anim. Sci. 6, 185-188.

Chumpawadee, S., Chinrssri, O., Somchan, T., Ngamluan, S. \& Soychuta, S., 2008. Effect of dietary inclusion of cassava yeast as probiotic source on growth performance, small intestine (ileum) morphology and carcass characteristic in broilers. Int. J. Poult. Sci. 7, 246-250.

Denstadli, V., Westereng, B., Biniyam, H.G., Ballance, S., Knutsen, S.H. \& Svihus, B., 2010. Effects of structure and xylanase treatment of brewers' spent grain on performance and nutrient availability in broiler chickens. Br. Poult. Sci. 51, 419-426.

El Boushy, A.R.Y. \& Van der Poel, A.F.B., 2000. Handbook of poultry feed from waste processing and use. Kluwer Academic, Netherlands.

Esonu, B.O., Anumni, P., Obinna, K. \& Eneremadu, O.F., 1999. Evaluation of combinations of maize/sorghum-based brewer's grains, cocoyam corm and cassava root meals as substitute for maize in broiler finisher diets. Indian $\mathrm{J}$. Anim. Sci. 69, 129-130.

Kokol, C., Zaklag, U., Antyev, M., Akade, F.T. \& Bab, A.M.J., 2012. Response of broiler finisher fed graded levels of brewers dried grain on carcass and internal organ characteristics. J. Agric. Vet. Sci. 4, 70-76.

Kumar, M. \& Sharma, B.D., 2004. Quality and storage stability of low-fat pork patties containing barley flour as fat substitute. J. Food Sci. Technol. 41, 496-502.

Lacassagne, L., Francesch, M., Caire, B. \& Mekion, J.P., 1998. Utilization of tannin containing and tannin free faba beans (Vicia Faba) by young chicks. Effects of pelleting feed on energy, protein and starch digestibility. Anim. Feed Sci. Technol. 20, 59-68.

Lin, C.C., Wu, S.J. \& Chang, C.H., 2003. Antioxidant activity of Cinnamomum cassia. Phytother. Res. 17, 726-730.

Longe, P.G. \& Adetolla, J.A., 1983. Metabolizable energy value of some agricultural wastes and industrial by-products for layers and effect of these ingredients on gut dimension. J. Anim. Prod. Res. 3, 2-13.

Lopez, J.D. \& Carmona, J.F., 1981. Feeding brewers' dried grains. In: A.R.Y. Boushy \& A.F.B. Van der Poel (eds), 1994. Poultry Feed from Waste. Chapman \& Hall, London, UK.

Munekata, P.E.S., Calomeni, A.V., Rodrigues, C.E.C., Avaro-Trindade, C.S.F, Alencar, S.M. \& Trindade, M.A., 2015. Peanut skin extract reduces lipid oxidation in cooked chicken patties. Poult. Sci. 94, 442-446.

Nath, R.L., Mahapatra, C.M., Kondaiah, N. \& Singh, J.N., 1996. Quality of chicken patties as influenced by microwave and conventional oven cooking. J. Food Sci. Technol. 33, 162-164.

NRC 1994. Nutrient requirements of poultry. National Research Council, 9th edition. National Academic Press, Washington DC, USA

O'Keefe, S.F. \& Wang, H., 2006. Effects of peanut skin extract on quality and storage stability of beef products. Meat Sci. 73, 278-286.

Rao, L.H., Khizar, L.Y., Karangwa, E., Xia, S.Q., Jia, C.C. \& Zhang, X.M., 2011. Effect of ultrafiltration and fining adsorbents on the clarification of green tea. J. Food Engin. 102, 321-326.

Rhee, K.S. \& Ziprin, Y.A., 2001. Pro-oxidative effects of $\mathrm{NaCl}$ in microbial growth controlled and uncontrolled beef and chicken. Meat Sci. 57, 105-112.

Saeed, M., Arain, M., Arif, M., Alagawany, M., Abd El-Hack, M.A., ..., Chao, S., 2017. Jatropha (Jatropha curcas) meal is an alternative protein source in poultry nutrition. World Poult. Sci. J. 73, 783-790.

Sarbaz, E, Navidshad, B. \& Aghjegheshlagh, F.M. 2018. The effect of peanut pod on performance, small intestine pH and ileum bacteria population in broiler chickens. S. Afr. J. Anim. Sci. 48, 435-444.

SPSS, 2008. Release 16, Statistical Package for the Social Sciences Inc, Chicago, USA. 
Su, Y.K., Bowers, J.A. \& Zayas, J.F., 2000. Physical characteristics and microstructure of reduced-fat frankfurters as affected by salt and emulsified fats stabilized with non-meat: Proteins. J. Food Sci. Technol. 65, 128-132.

Swain, B.K., Naik, P.K., Chakurkar, E.B. \& Singh, N.P., 2012. Effect of feeding brewers' dried grain on the performance and carcass characteristics of Vanaraja chicks. J. Appl. Anim. Rese. 40, 163-166.

Vasso, O. \& Russ, W. 2007. Utilization of by-products and treatment of waste in the food industry, Springer Science. New York, NY, USA: Springer.

Wondifraw, Z. \& Berhan, T., 2014. The effect of feeding different levels of brewer's dried grain yeast mixture on the performance of White Leghorn chicks. Int. J. Livest. Prod. 5, 10-14. 